\section{Battle renewed over value of fluoridation}

Linking the decision made by the United States Department of Health and Human Services to lower the recommended level of fluoride added to drinking water to the effectiveness of water fluoridation is inaccurate. ${ }^{1}$

This decision was based on studies showing that the levels previously accepted in the US presented a risk of dental fluorosis that was deemed unacceptable for infant formula reconstituted with tap water. The change was a dosage adjustment, not a retreat from water fluoridation. The reference to the balance of protection and risk confirms that the decision had nothing to do with "bone effects" and everything to do with fluorosis. There is no evidence that exposure to fluoride from water fluoridation leads to bone abnormalities of any kind.

The decisions by some municipalities to remove fluoride are a series of political decisions, not decisions based on scientific evidence. Further, several Canadian municipalities have recently voted in favour of keeping fluoride in their water. ${ }^{2-4}$ Dental disease is the number one chronic disease among children and adolescents in North America, and optimally fluoridated water is a safe and cost-effective public health benefit.

Over 90 national and international scientific and medical organizations, including the Canadian Medical Association, support the use of fluoride as a safe and effective measure to prevent tooth decay. ${ }^{5}$

One final point: Grand Rapids, Michigan, was the first city in the world to start water fluoridation in 1945, not in 1975, as stated in the CMAJ article.

\section{Robert MacGregor BSc, DDS}

President, Canadian Dental Association, Ottawa, Ont.

\section{References}

1. George C. Battle renewed over value of fluoridation. CMAJ 2011;183:E531-2.

2. Peat D. Toronto will continue fluoridation of the water supply. Toronto Sun 2011 Apr. 4. Available: www.torontosun.com/news/torontoandgta/2011/04 /04/17870616.html (accessed 2011 June 8).

3. The Canadian Press. CBRM council votes to keep fluoride in municipal water. 2011 Apr. 20. Available: www.globalmaritimes.com/CBRM+council +votes+keep+fluoride+municipal+water/4640062/ story.html (accessed 2011 June 8).

4. Gauthier G. Fluoride will stay. Lethbridge Herald 2011 Apr. 19. Available: www.lethbridgeherald .com/front-page-news/fluoride-will-stay-41911.html (accessed 2011 June 8).
5. It's your health: Fluoride and human health. Ottawa (ON): Health Canada; 2010. Available: www.hc-sc .gc.ca/hl-vs/iyh-vsv/environ/fluor-eng.php (accessed 2011 June 8).

CMAJ 2011. DOI:10.1503/cmaj.111-2054

\section{Adverse drug reactions}

The concern expressed in the editorial about prescribing information for children is real. ${ }^{1}$ Immature organ systems, especially the nervous system, are much more susceptible than mature organ systems to adverse effects by medical agents or other chemicals. In a Danish registry study, the pediatric population was found to be particularly vulnerable. $^{2}$

Perhaps a combination of translational methods with maturational studies $^{3}$ can provide a better idea of the mechanisms and effects of new agents in a developing organ.

Heikki Savolainen MD

Department of Occupational Safety and

Health, Tampere, Finland

\section{References}

1. Peterson B, Hébert PC, MacDonald N, et al. Industry's neglect of prescribing information for children. CMAJ 2011;183:994-995.

2. Aagaard L, Hansen EH. Adverse drug reactions from psychotropic medicines in the paediatric pop- 
ulation: analysis of reports to the Danish Medicines Agency over a decade. BMC Res Notes 2010;3: 176.

3. Savolainen H. Differentiation of human cortical neurons: proteins of subcellular particles. Comp Biochem Physiol B 1973;44:467-472.

CMAJ 2011. DOI:10.1503/cmaj.111-2055

\section{Concussion in youth hockey}

In his article on concussion in youth hockey," Johnson writes that "Crosby has a lot of company in the NHL [National Hockey League], where the number of concussions doubled in the 2010/11 season," "citing a reference to www.nhl.com. ${ }^{2}$ This is in error.

The cited article does not say that. In fact, NHL Commissioner Gary Bettman is reported to have handled the question of number of concussions this season as follows: "Bettman declined to reveal any numbers regarding the number of concussions sustained this season or what percentage they have risen to." $" 2$

Another NHL release reports: "Accidental concussions have nearly doubled this season from last season. In 2010 11, NHL Hockey Operations has determined that $26 \%$ percent of the League's reported concussions were the result of accidents. According to the terms of the study, accidental concussions involve a hit from a teammate, a trip or fall (not caused by an opponent), being struck by a puck or an inadvertent collision with an opponent." ${ }^{\prime 3}$ The NHL has reported that $26 \%$ of concussions for this season are accidental, $44 \%$ legal, $17 \%$ illegal, and $8 \%$ fight-related; the remaining 5\% are undefined because no videos of the incidents exist. ${ }^{4}$

Johnson appears to be confused by this breakdown and the reporting of concussions by the NHL. I can find no report of the actual number of concussions for the 2010-2011 NHL season. I ask why "Bettman declined to reveal any numbers regarding the number of concussions sustained this season."

\section{David Rhine MD}

Department of Emergency Medicine, Kelowna General Hospital; clinical instructor, Department of Emergency Medicine, University of British Columbia, Kelowna, BC

\section{References}

1. Johnson LSM. Concussion in youth ice hockey: It's time to break the cycle. CMAJ 2011;183:921-4.

2. Associated Press. NHL concussions on rise, accidental hits blamed. 2011 Jan. 29. Available: www.nhl.com/ice/news.htm?id=551016 (accessed 2011 May 25).

3. Associated Press. Study: time lost from illegal hits are down. 2011 Mar. 14. Available: www.nhl.com /ice/news.htm?id=555980 (accessed 2011 May 25).

4. Associated Press. Bettman discusses concussions, player safety. 2011 Mar. 14. Available: www.nhl .com/ice/news.htm?id=556046 $($ accessed 2011 May 25).

CMAJ 2011. DOI:10.1503/cmaj.111-2052

I believe the issue raised by Dr. Rhine would benefit from some clarification.

Although the NHL declines to release figures on the number of concussions, it acknowledges that concussions are "on the rise" in the 20102011 season. ${ }^{1}$ The league attributes the increase to accidental hits, which account for $26 \%$ of concussions. ${ }^{2}$ The number of concussions attributed to accidental hits in the 2010-2011 season nearly doubled from the previous season. ${ }^{2}$ Legal hits account for $44 \%$ of reported concussions in the 2010-2011 season. ${ }^{2}$

\section{Syd M. Johnson MA PhD}

Novel Tech Ethics, Dalhousie University, Halifax, NS

\section{References}

1. Associated Press. NHL concussions on rise, accidental hits blamed. 2011 Jan. 29. Available: www .nhl.com/ice/news.htm?id=551016 (accessed 2011 May 25).

2. Associated Press. Study: time lost from illegal hits are down. 2011 Mar. 14. Available: www.nhl .com/ice/news.htm?id=555980 $($ accessed 2011 May 25).

CMAJ 2011. DOI:10.1503/cmaj.111-2053

\section{Letters to the editor}

In submitting a letter, you automatically consent to have it appear online and/or in print. All letters accepted for print will be edited by $C M A J$ for space and style. Most references and multiple authors' names and full affiliations will appear online only. (The full version of any letter accepted for print will be posted at cmaj.ca.) 